\title{
Halal Culinary Tourism Promotion Strategy in Improving Performance Small and Medium Enterprises Through Digital Marketing in Batam City
}

\author{
Yudha Trishananto", Dinda Inti Nur Arianti and Esa Dilla Maulani ${ }^{1}$ \\ ${ }^{*}$ Faculty of Islamic Economics and Business, IAIN Salatiga, Indonesia
}

\begin{abstract}
This study aims to provide a stimulus to the leading sectors that contribute to the state budget countries from the non-oil and gas sector. So far, tourism has an extraordinary strategic function in terms of food security and job creation for the community. This brings a breath of fresh air in the home industry which is the supporter of the country's economy, how can I not? $65 \%$ of the contribution of the economy in Indonesia is contributed by industrybased MSMEs household. Batam is a special economic area that has extraordinary potential in tourism development. Its strategic location is close to the ASEAN economic center, namely Singapore provides advantages for tourism development at this time, especially related to tourism culinary tour. Culinary and tourism are cultural identities to introduce potential an area to outsiders. In connection with this study, the researcher examines the existence of digital marketing as an accommodation for SMEs in promoting culinary products halal through social media, search engine marketing and online websites. This research takes the sample on consumers who buy halal food produced by SMEs in Batam is 160 respondents where in the application in the field proportional sampling method is used .. research The field took place in 7 sub-districts in Batam, namely Tembesi, Batam Center Sekupang, Sei Beduk, Nongsa, Sagulung. This research uses Structure Equation Model (SEM) analysis. so that it is easy to reveal problems that have not been answered in previous research. Keywords: Halal Culinary Promotion; Digital Marketing; MSME performance
\end{abstract}

\section{Introduction}

Micro small and Medium Enterprises (UMKM) is one part of important part of a nation's economy and area. MSME activities at this time tend to survive more than large-scale business, can not be denied again that one of the sectors that supports Indonesia's economy is a sector this business. With the help of this business sector all aspects of human life starting from consumption, food and board sectors who play an active role in encouraging

* Corresponding author: yudhatrishananto@iainsalatiga.ac.id 


\section{$A I \overline{C E B}$ Annual International Conference \\ on Islamic Economics and Business, 2021}

enhancement economy national. MSME activities include various activities economy but also mostly in the form of a small business engaged in service sector and home-based businesses. In The macroeconomic principles of MSMEs have strategic role in national income and reducing unemployment .

The development of SMEs in the city of Batam emerged starting from the start of the decline of the industry manufacturing as initial support free trade zone economy in 2015 ago. This gives rise to several social problems, namely the emergence of numbers unemployment when many companies multinationals leave this island.Less more than 50\% of the people of Batam are manufacturing company employees in the field of shipyard and electronic. Based on this problem gradually productive age change their livelihood as entrepreneurs in various fields such as services, culinary, and there is a master plan new that Batam's economic assets will rotated 180 degrees into a region special economy where $40 \%$ will donated from sector development tourist. According to (El-Gohary, 2016) Characteristics Performance of SMEs is a basic trait or factual conditions attached to business activities and entrepreneur behaviour concerned in carrying out his business. Lately, marketing results MSME production is not only distributed through method method trading conventional (offline) but mostly has penetrated into the marketing digital nature. Digital marketing is one of the marketing strategies for promote a brand with using digital media that can reach consumers precisely time, personal and relevant.

Many techniques and practices that must be applied in digital marketing category (online) still have a dependency on marketing offline which nature conventional gave rise to a new thought that digital marketing is able to combine main elements such as gadgets, deep web display products and banners, with combine strategy marketing conventional and digital, activities promotion to be more optimal and efficient. In digital marketing, there are several factors in it, namely the psychology, economics, and technology that will become a new medium with a large capacity, interactive and multimedia. The result of a new era in the form of interactions between producers, intermediaries market and consumers. To date digital marketing is being expanded to support company services and engagement from consumers. (Marketing et al., 2013) The results of empirical research Geissinger et al., (2018) in a study entitled "Digital entrepreneurship and field conditions for institutional change investigating the enabling role of cities" in this research stated that government regulations facilitates a lot of home-based businesses that digital-based where it has been able awaken economy city Stockholm Sweden.. In implication hope for more future research emphasizes areas that have different characteristics with research the. So on this basis it was developed research model applied to another domain is marketing development digital for MSMEs that produce Culinary products. In addition, other references are based on empirical research (Yousaf \& Xiucheng, 2018) in his research entitled " halal " culinary and tourism marketing strategies on government website: a preliminary analysis" There are limitations in this research namely only reviewing qualitative reviews on halal culinary at offline marketing at developed countries.

\section{Literature Review}

\subsection{Promotion of Halal Culinary Tourism}

Promotion is one of the activities from marketing. (Razzaq et al., 2016) promotion is a tool and a technique marketing used to create product or service to make it look more attractive by providing several benefits addition or provide added value to potential customers so that they are interested to buy or consume the product or services offered.(Geissinger et al., 2018) mentions that the main function promotion is to communicate with customers and touch the hearts of customers to be interested in buying or willing to stay loyal to consume the product or service offered.according to the Tourism Association International Culinary Tourism Association / ICTA) is an activity unique eating and drinking by every traveling traveller 


\section{$A \mathrm{IC} \quad$ Annual International Conference \\ on Islamic Economics and Business, 2021}

(Martínez et al., 2014). The words "halal" and "haram" is a term found in the book sacred to Muslims, namely the Qur'an. This term used in various ways with different concepts, and part of it related to food and drink. Halal in language according to some opinion means something it is permissible according to the Shari'ah to do so, used or cultivated, because it has been unravel the ropes or ties that prevent it or elements that harm it with accompanied by attention to how to obtain it, not with the result of "muamalah" which prohibited (Albala \& Regenstein, 2015)

\subsection{Digital Marketing}

Marketing of products and services with using digital channels (technology) to get new customers and build Preference customer, promote the brand, maintain customers, and increase sales. This definition is also in line with the found by the AMA, which mentions that digital marketing can be seen as an activity, institution, and processes facilitated by digital technology to create, communicate, and provide value to customers and other stakeholders (Geissinger et al., 2018). As for one form of digital marketing is marketing that done online via the internet or electronic media so that digital marketing (digital marketing) is often also known with the term internet marketing, e- marketing, or online marketing.

\subsection{MSME Performance}

(Martínez et al., 2014)defines organizational performance as how well organization is managed and how much value that the organization provides to customers and other stakeholders (including shareholders or investors). (Wibowo \& Grandhi, 2017) stated that the performance of SMEs can be seen from the satisfaction of the business owner or manager of profit, turnover, return stage capital (break even points), and business development. (Ndiaye et al., 2018) stated that the assessment of MSME performance can be viewed from several perspectives: aspects, including (1) added value; (2) business units, workforce, and productivity; and (3) export value. Furthermore, (BI \& LPPI, 2015) mentioned that the development of SMEs in Indonesia can be influenced by several factors, both internal and external factors external factors.

\section{Research Method}

Sampling technique with using cluster sampling Which continued with the operationalization of variables, hypothesis testing plan to method data analysis used using Structural Equation Model with units analysis (sample) of MSME business actors which produces Halal Culinary in the city Batam as many as 160 respondents. Study This is a survey of business actors MSME-based halal culinary in the city of Batam spread over seven (7) sub-districts in Kota Batam, Riau Islands. Secondary data obtained at the Office of Industry at Jln REMartadinata, Sekupang, City Batam. The population in this study is all consumers of culinary MSME products Halal which is spread over seven sub-districts in Indonesia Batam City. Due to the total population in This research is very large and based on quantitative paradigm considerations are not efficient and ineffective when done research on the population, then in This study used the sample as a the subject.

\section{Results and Discussion Results}

The use of CFA in SEM is carried out on two measurement models, namely the variable endogenous, namely the promotion of halal culinary tourism and Digital Marketing with consideration theoretically that each item has been studied to measure the construct each. The basis of analysis emphasizes on the content validity of each each construct. Related to this the researcher adapts the items taken from the next international journal literature the items are adapted into the phenomenon of MSME performance appraisal so that on the representation of the final results of the research it's solely not only on the results empirical only. Study of two factors in this manuscript consists of several studies taken from one 


\section{$A I \overline{C F B} \quad$ Annual International Conference \\ on Islamic Economics and Business, 2021}

medium sample-based study consisting of 160 respondents. Step Next, the researcher divides into two sub sample with mean split technique, basic the main division is high social capital and low in the mind entrepreneurs who fill out a questionnaire this research. In Structural Equation Model analysis there is no single statistical test tool for measure the degree of suitability of the model (Ghozali, 2013; Marketing et al., 2013) . For that you need to use multiple suitability models to assess whether the model fits the data. Validation results using CFA ( confirmatory factor analysis ) on both sub-sample of halal culinary business actors it shows that the model two factors, namely Halal Culinary Promotion and Digital marketing in general has goodness of fit is good seen from the table below below:

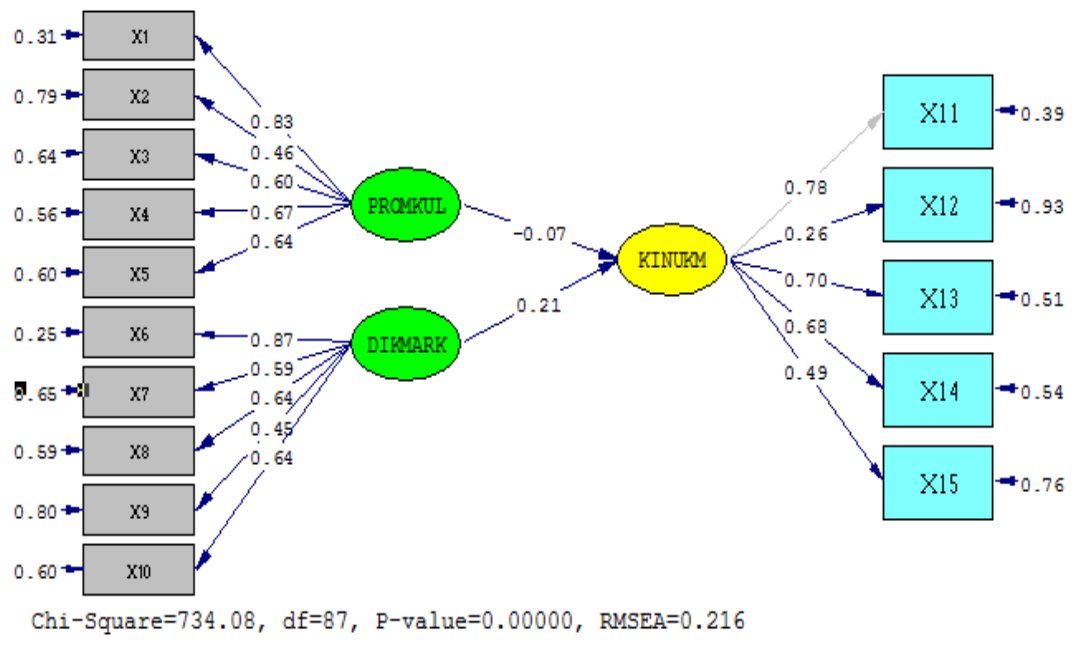

The chi square criterion is very sensitive with the sample size so that it must be equipped with other test equipment. The smaller the value chi square the better the result is also the significance probability if not significant at $p>0.05$ means no the difference between the model and the data. AGFI and GFI is used to calculate weighted proportion of the variance in estimated population covariance matrix(Kurniawan et al., 2016). GFI in regression model analogous to $\mathrm{R}$ square, level recommended reception is when GFI and AGFI have the same value or greater than 0.90. CFA validation results both samples show that GFI > 0.90 so it can be said to have the fit of the model is relatively good.

Discussion

RMSEA is an index that can be used to compensate Chi Square statistics. Smaller RMSEA or equal to 0.22 is the index acceptable model. By empirical from the acquisition of the results obtained with values 5.03 and 0.62 . This matter shows the number 0.47 so that it can be said that there is a model fit with data. The results of each validation item indicates that all four items on Culinary promotion constructs have a factor loading above 0.5 that is $\mathrm{X} 11=0.52, \mathrm{X} 12=0.61 \mathrm{X} 13=0.74$ and $\mathrm{X} 4=0.66$. Thing it shows that each each item describes the construct better. While the 6 items on the construct of Halal Culinary tourism promotion has a general loading factor above 0.5 except X11 $=0.46$ but still in tolerance limit. Likewise the five items on The digital marketing construct has a factor loading above 0.5 that is $\mathrm{X} 21=0.62, \mathrm{X} 22=0.73, \mathrm{X} 23=0.53, \mathrm{X} 24=0.71, \mathrm{X} 25=0.74 \mathrm{X} 26=0.63$, while the six items on culinary entrepreneur sample shows results above 0.5 except X21 $=\mathrm{N} 0.46$ but still within the tolerance limit of 0.4 (Ferdinand, 2013). By looking at the suitability of the model and loading factor for each construct then the promotional items for halal culinary tourism and digital marketing in the phenomenon MSME performance appraisal has results 


\section{$A \mathrm{IC} \quad$ Annual International Conference \\ on Islamic Economics and Business, 2021}

good validation in each sample that used by this institution both on different characteristics that are have high interest and enthusiasm.

\section{Conclusion and Suggestions}

The studies in this study provide empirical picture related to insight and knowledge about tourism promotion halal, digital marketing and MSME performance. Culinary business actors are a sector SMEs in Batam in practice application in the field using multidimensional business risk factors and presentation of the demographic conditions of the actors MSMEs are mainly related to the market halal food distributed online with media intermediaries webbased trading such as Bukalapak, Shoppie and Gojek. Modeling promotion of halal culinary through digital marketing related to MSME performance give response positive for increase profits and business flows that positive. This will support the output people's economy significantly especially the development of culinary tourism in Indonesia the city of Batam in a sustainable manner.

Answer from Structure Equation Model provide a significant general effect and contribute positively to the use of the concept of digital marketing as a medium intermediation on performance improvement SMEs so it can be recommended as a reference for effective marketing creativity in the future associated with risk faced in the perception of halal food at this time. Findings in this study intended in accordance with research results earlier (Geissinger et al., 2018) where in the results of his research on the intensity of food products Halal is naturally the higher the output when using online marketing. But the results of previous studies (Yousaf \& Xiucheng, 2018) opposite to the results of this study which provide description by psychological for improve measurement and distribution halal food industry with perception product risk and satisfaction turning point consumer.

The positive side of knowledge SMEs actors in trust and consumer satisfaction intensity recommended with target demographics and characteristics of consumers who consuming halal culinary produced by SMEs in Batam. This is about the difference age, gender in this study are in line with the answers of previous researchers with different scientific disciplines. The results of this research show variations in consumer behavior and online web user satisfaction as online business mediator found there fundamental difference between actors MSMEs with 36 months of business with $>48$ months. From this answer can known intensity of marketing demographics digital technology proves to be very heterogeneous if crossed with the output intensity accepted by MSME actors in Batam city large. The findings in this study provide comparison test between MSME actors Halal culinary with consumers providing positive effect on the culinary MSME business in Indonesia Batam in developing strategy target oriented marketing consumer satisfaction. level of confidence online web users in marketing Halal culinary gives a positive aura outline market plans regularly will well organized. Every consumer halal culinary production of SMEs in Batam able to influence the business environment and customer satisfaction. It fits with research (Ndiaye et al., 2018). Representation from results descriptive shows MSME actors with a level of higher education is more creative in wise decisionmaking process so that the main priority of the target market can be served with care.

\section{Research limitations and research agenda coming}

Cross sectional data were collected and the actors MSME-based culinary business only producing halal food in Batam city as an industrial and supporting area tourism in the Riau Islands province. These findings and research are actually still does not yet represent the views and consumers in halal culinary productivity in other areas that have a background different where many institutions and individuals have a different perspective. this study focus on SMEs only so the answer from this researcher can not be generalized in other halal business lines such as cosmetics, banking and medical services. Future research can take the 


\section{$A I \overline{I E B} \quad$ Annual International Conference \\ on Islamic Economics and Business, 2021}

subject on institutions and segmentation that in-depth on halal products in businesses that are different. It aims to expand comprehensive scope and results. Future research is expected to be more take into account culture, dogma religion that is able to go deeper explore more research results specifically related to this study.

\section{References}

Albala, K., \& Regenstein, J. M. (2015). Halal Food. SAGE Encyclopedia of Food Issues.

BI \& LPPI. (2015). Profil Bisnis Usaha Mikro, Kecil dan Menengah (UMKM). Bank Indonesia dan LPPI.

Ferdinand, A. T. (2013). Company Specific Advantage and Sustainable Competitive Advantage. SSRN Electronic Journal.

Geissinger, A., Laurell, C., Sandström, C., Eriksson, K., \& Nykvist, R. (2018). Digital entrepreneurship and field conditions for institutional change- Investigating the enabling role of cities. Technological Forecasting and Social Change. Technological Forecasting and Social Change.

Ghozali. (2013). Teori Motivasi dan Pengukurannya. Kajian Pendidikan Akuntansi Indonesia, 4.

Kurniawan, A., Loekito, L., \& Solimun, S. (2016). Power of Test Path Analysis and Partial Least Square Analysis. CAUCHYDO, 4, 112-114.

Marketing, C., D, M, \& S. (2013). Digital Media and Sustainable Marketing. Journal of Chemical Informantion and Modelling, 1689-1699.

Martínez, R., Galvan, M., \& Lafuente, A. G. (2014). Public Policies and Tourism Marketing. An Analysis of the Competitiveness on Tourism in Morelia, Mexico and Alcala de Henares, Spain. Procedia - Social and Behavioral Science, 146-152.

Ndiaye, N., Abdul, L., Nagayev, R., \& Ng, A. (2018). Borsa _ Istanbul Review Demystifying small and medium enterprises' ( SMEs ) performance in emerging and developing economies. Borsa Istanbul Reviews.

Razzaq, S., Hall, C., \& Prayag, G. (2016). The capacity of New Zealand to accommodate the halal tourism market - Or not. Tourism Management Perspectives, 92-97.

Yousaf, S., \& Xiucheng, F. (2018). Halal culinary and tourism marketing strategies on government websites: A preliminary analysis. Tourism Management, 423-443. 